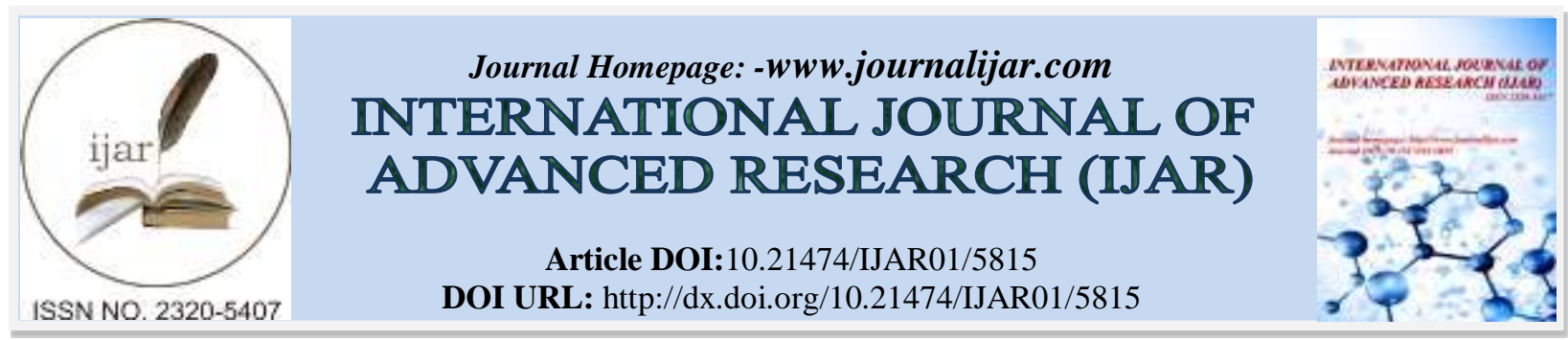

RESEARCH ARTICLE

\title{
ENHANCEMENT OF MANGOSTEEN (Garcinia mangostana) ORGANOGNENESIS USING EXPLANTS FOR ITS BENEFICIAL DEMANDS.
}

\section{A. Parsana (P.T) ${ }^{1}$ and D. Sathish Sekar ${ }^{2}$}

1. Research Scholar, Periyar University, Salem, Tamil Nadu, India.

2. Associate Professor, Department of Biotechnology, PEE GEE College of Arts \& Science, Dharmapuri, Tamil Nadu.

\section{Manuscript Info}

\section{Manuscript History}

Received: 09 September 2017

Final Accepted: 11 October 2017

Published: November 2017

Key words:-

Mangosteen, Propagation, Seeds,

Leaves, Survival, Initiation

\begin{abstract}
Mangosteen, Garcinia mangostana L. is the most delicious tropical fruit and has been called the 'the queen of fruits' or the 'finest fruits of the world'. Mangosteen has various beneficial properties in different parts of the plant. They possess various antioxidants that are responsible for treating cardio problems. Moreover, it shows positive for the antifungal and anti-inflammatory properties which heal several disorders. In order to make use of these medicinal properties and nutritional benefits from Mangosteen, the plant production should be higher. On the other hand, rejuvenation of the plants has not been fully successful since the plants are growing and fruiting slowly. Plant propagation through seeds has several problems. A plant grown from seed will fruit for the first time after 15-17 years. The plant bears fruit only once or twice a year and each fruit have only one or two good seeds which are very tedious for the traditional propagation. In addition, Mangosteen seeds are recalcitrant which will not survive for long time, therefore continuous plant propagations by seeds are difficult. Vegetative propagation has not been fully successful as the succeeded plants grow very slowly; they will be weak, not uniform, and slow flowering. Hence, the mass propagation of uniform, good performance and continuous annual supply of plant material can be achieved through Micropropagation. In this study, the explants survival and the initiation of survived explants were recorded after various trials using the seeds and leaves as explants.
\end{abstract}

Copy Right, IJAR, 2017,. All rights reserved.

\section{Introduction:-}

The Unique Mangosteen:-

Mangosteen is a humid low land tropical forest tree which is slow growing, upright in habitat, with a pyramid shaped crown. It requires an equatorial climate, a high even temperature with high humidity for its growth. Temperature ranging from $20^{\circ} \mathrm{C}$ to $33^{\circ} \mathrm{C}$ is desirable for its optimum growth (Tran Van Minh, 2005). It is distributed throughout the tropics, but primarily in Thailand, Malaysia, the Philippines, Indonesia, Brazil, Honduras, Panama, and Hawaii, USA. In India, Mangosteen grows in four areas such as Nilgiri hills, the southern districts of Tinnevelly and Kanyakumari in Tamil Nadu, and Kerala which are tropical with high humidity and moderate rainfall. In Tamil 
Nadu, the trees grow from250ft to 5,000ft elevation (Mohammad Hossein Torabi Sirch et al., 2008).

\section{The fruit:-}

Mangosteen belongs to the medium tree category which is 30-60 feet $(9-18 \mathrm{~m})$ tall, with a straight trunk and a rounded, dense crown. The new bark of Mangosteen is bright green and smooth and rough with age. The thick leaves are elliptical and bright green, from 3-6 inches in length. The flowers are solitary or in pairs at the branch apex, 1-2 inches in diameter, with 4 pinkish white petals and 4 persistent sepals (H. K. L. Goh et al., 1998). The fruit is round, 2-3 inches in diameter, with a thick purple rind surrounding 4-8 fruit segments. The pulp is aromatic and has a delightful sweet sour taste. Usually only one enlarged segment has a viable seed, which is flattened and about $1 / 2$ inch long (Tran Van Minh, 2005).

Mangosteen has no hint of sourness or acidity. Its uniform sweetness and lack of astringency symbolizes that the fruit is not moody fruit like jamun, and it is not fickle with an ever-changing flavor like longan (Ika Rostika et al., 2008). It is highly nutritious which contains Carbohydrates of about 6-20 g; Proteins of about 0.6 g; severalvitamins such as A, C, B1, B2 and Niacin ranging from $0.03-0.3 \mathrm{mg}$ (Mohammad Hossein Torabi Sirch et al., 2008).

\section{Demands Of The Fruit:-}

1. Delicious and juicy, mangosteen is one of the popular tropical fruits. It comprises of an impressive list of essential nutrients which required for normal growth and development and overall nutritional well-being.

2. It is moderately low in calories (63 calories per $100 \mathrm{~g}$ ) and contains no saturated fats or cholesterol. Nonetheless, it is rich in dietary fiber (100 g provides about 13\% of RDA) (Sompong Te-chato, Mongkol Lim, 1999).

3. Mangosteen is a good source of Vitamin-C and provides about $12 \%$ of RDA per $100 \mathrm{~g}$. Vitamin-C is a powerful water soluble antioxidant. Consumption of fruits rich in vitamin-C helps the human body develop resistance against viral flu and help scavenge harmful, pro-inflammatory free-radicals.

4. Fresh fruit is a mild source of B-complex vitamins such as thiamin, niacin, and folates. These vitamins are acting as cofactors the help body metabolize carbohydrates, protein, and fats (FauziyahHarahap et al., 2014).

5. Further, it also contains a splendid amount of minerals like copper, manganese, and magnesium. Potassium is an important component of cell and body fluids and helps control heart rate, and blood pressure, thus, it offers protection against stroke and coronary heart diseases

6. The fruit rind is ground and used in the treatment of diarrhea and dysentery, and for skin diseases. A tea made from the leaves and bark is used to lower fever and for urinary disorders.

7. The tree, with its glossy green leaves and symmetrical shape, is also a beautiful ornamental (Sompong TeChato, 2004).

\section{Materials and method:-}

\section{Plant procurement:}

The Mangosteen plants were collected from the nursery and maintained in the Genewin Biotech, Hosur for easy acclimatization.

\section{Explant Excision:-}

The explants such as seeds from a matured ripen mangosteen fruit were collected along with the leaves which were trialed for the mass propagation both by Direct and Indirect organogenesis.

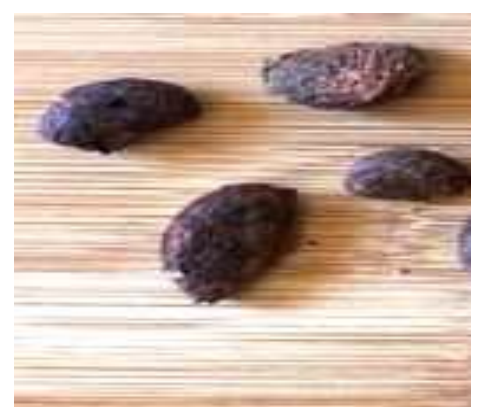

a) Seeds

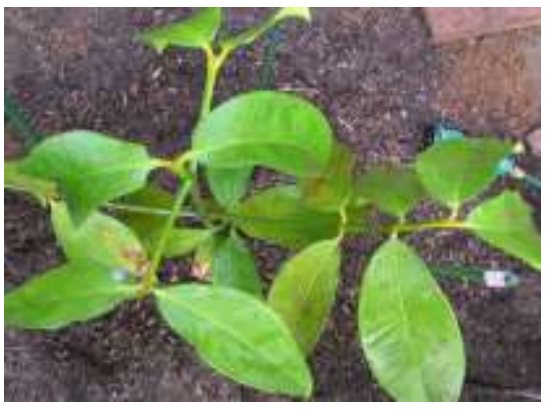

b) Leaves

Fig 1: Collection of Explants 


\section{Surface sterilization:-}

Mangosteen leaves obtained from mature trees and seeds were excised to 1 x $1 \mathrm{~cm}$ square segments. The explants were shaken in antifungal and antibacterial solution, carbendazim $(0.1 \%)$ and streptocycline $(0.1 \%)$ for 15 minutes. The sterilization is followed by wiping of explants very carefully using ethanol with sterilized cotton for the removal of layers of dust or microbes. Finally, explants were treated using detergent, Polysorbate 20 for 20 minutes. The explants were washed with sterile water three times to ensure the complete removal of foam.

The sterilization is further carried out inside laminar air flow chamber using surface sterilant and 3 sets of experiments were performed (Mohammad Hossein Torabi Sirch et al., 2008).

SET 1: Mercuric chloride $(0.1 \%)$ as surface sterilant for 3, 5, 7, 9min. The explants were removed from the mercuric chloride solution and washed with sterile water 3 times to eliminate the toxic effects of Mercuric chloride.

SET 2: Sodium hypochlorite $(\mathrm{NaOCl})$ as surface sterilant at various concentrations such as $10 \%, 20 \%$ and $30 \%$ for $20 \mathrm{~min}$.

SET 3: Ethanol of $70 \%$ concentration was treated on the explants for about $1-5 \mathrm{~min}$ as the surface sterilant and observed for the response.

The response was recorded in each trial in 3- 4 weeks (Ika Rostika et al., 2008).

\section{Mortality Rate:-}

Mortality rate, or death rate, is a measure of the number of deaths (in general, or due to a specific cause) in a particular population, scaled to the size of that population, per unit of time.

The Mortality rate was calculated by

$\%$ Mortality $=$ Explants contaminated $\times 100$

$$
\text { Total no of Explants }
$$

\section{Commencement of Growth of Explants:-}

Initiation stage gives rise to regeneration of new shoots from the selected explants in 15 days. The growth was frequently monitored every week and recorded. The surface sterilized explants were inoculated in following MS basal media treatments + Sucrose $3 \%$ with various growth regulator concentrations.

IM 1: $6 \mathrm{BAP}-0.5 \mathrm{mg} / \mathrm{l}+\mathrm{IBA}-1 \mathrm{mg} / \mathrm{l}+\mathrm{NAA}-1 \mathrm{mg} / \mathrm{l}$

IM 2: $6 \mathrm{BAP}-1 \mathrm{mg} / \mathrm{l}+\mathrm{IBA}-1 \mathrm{mg} / \mathrm{l}+\mathrm{NAA}-1 \mathrm{mg} / \mathrm{l}$

IM 3: $6 \mathrm{BAP}-1.5 \mathrm{mg} / \mathrm{l}+\mathrm{IBA}-1 \mathrm{mg} / \mathrm{l}+\mathrm{NAA}-1 \mathrm{mg} / \mathrm{l}$

IM 4: $6 \mathrm{BAP}-2 \mathrm{mg} / \mathrm{l}+\mathrm{IBA}-1 \mathrm{mg} / \mathrm{l}+\mathrm{NAA}-1 \mathrm{mg} / \mathrm{l}$

IM 5: $6 \mathrm{BAP}-2.5 \mathrm{mg} / \mathrm{l}+\mathrm{IBA}-1 \mathrm{mg} / \mathrm{l}+\mathrm{NAA}-1 \mathrm{mg} / \mathrm{l}$

The explants were placed in the prepared media; each treatment consisted of 3 replicates and the mean parameters were calculated. The inoculated jars were incubated (Ika Rostika et al., 2008).

\section{Culture Conditions:-}

The explants are subjected under light intensity for 10-12 hours in the growth room. Photoperiod provided by cool white fluorescent lamps of 1500-3000 lux, temperature of about $25 \pm 2{ }^{\circ} \mathrm{C}$ and humidity of $35-40 \%$. The observation will be recorded after 4-5 weeks (Sompong Te-Chato, 2004).

\section{Results and discussion:-}

Effect of surface sterilization - seeds:

Surface sterilization using seeds as explants were done using Mercuric chloride, Sodium hypochlorite and Ethanol at various concentrations and timings were trialed out and the observations were tabulated.

\begin{tabular}{|c|c|c|c|c|}
\hline $\begin{array}{l}\text { TREATMENT OF } \\
\text { MERCURIC } \\
\text { CHLORIDE }(\%)\end{array}$ & $\begin{array}{c}\text { NO OF } \\
\text { EXPLANTS } \\
\text { TAKEN }\end{array}$ & $\underset{(\%)}{\text { MORTALITY RATE }}$ & $\begin{array}{l}\text { NO OF EXPLANTS } \\
\text { NOT RESPONDED }\end{array}$ & $\begin{array}{c}\text { SHOOT } \\
\text { RESPONSE } \\
(\%)\end{array}$ \\
\hline $0.1 \% \mathrm{HgCl}_{2}-3 \mathrm{~min}$ & & $80 \pm 0.23$ & $20 \pm 1.21$ & 0 \\
\hline $0.1 \% \mathrm{HgCl}_{2}-5 \mathrm{~min}$ & & $72 \pm 0.36$ & $27 \pm 0.88$ & $1 \pm 2.33$ \\
\hline $0.1 \% \mathrm{HgCl}_{2}-7 \mathrm{~min}$ & & $69 \pm 0.3$ & $28 \pm 0.76$ & $3 \pm 1.88$ \\
\hline $0.1 \% \mathrm{HgCl}_{2}-9 \mathrm{~min}$ & & $63 \pm 0.31$ & $31 \pm 0.68$ & $6 \pm 1.5$ \\
\hline $10 \% \mathrm{NaOCl}-20 \mathrm{~min}$ & & $49 \pm 0.35$ & $35 \pm 0.6$ & $16 \pm 0.44$ \\
\hline
\end{tabular}




\begin{tabular}{|c|c|c|c|c|}
\hline $20 \% \mathrm{NaOCl}-20 \mathrm{~min}$ & \multirow{5}{*}{20} & $50 \pm 0.33$ & $30 \pm 0.55$ & $20 \pm 0.33$ \\
\hline $30 \% \mathrm{NaOCl}-20 \mathrm{~min}$ & & $45 \pm 0.43$ & $27 \pm 0.88$ & $28 \pm 0.21$ \\
\hline $70 \%$ Ethanol $-1 \mathrm{~min}$ & & $28 \pm 0.62$ & $38 \pm 0.73$ & $34 \pm 0.11$ \\
\hline $70 \%$ Ethanol $-3 \mathrm{mins}$ & & $21 \pm 0.77$ & $33 \pm 0.69$ & $46 \pm 0.08$ \\
\hline $70 \%$ Ethanol $-5 \mathrm{mins}$ & & $9 \pm 1.03$ & $10 \pm 0.2 .1$ & $81 \pm 0.03$ \\
\hline
\end{tabular}

Table-1: Effects of surface sterilization - seeds

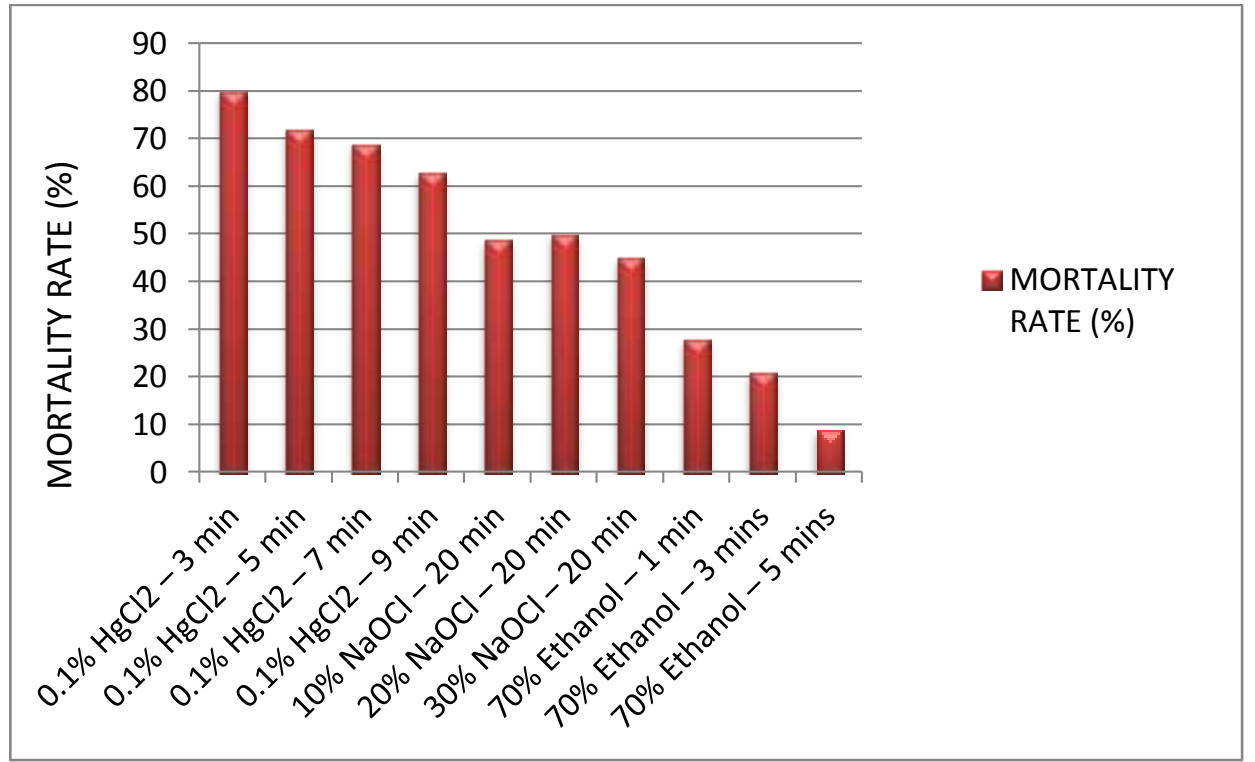

Graph 1:- Mortality rate with surface sterilants - seeds

Majority of the explants survived after treatment when they were exposed to Ethanol $70 \%$ for about $5 \mathrm{~min}$. Treatment with 1and 3 min were found with slight mortality of the explants whereas treatment with Mercuric chloride and Sodium hypochlorite at various concentrations and timings exposure led to the larger rate of mortality and some of them were non-responsive. Shoot response was observed to $81 \%$ using Ethanol $70 \%$ as the best treatment at $5 \mathrm{~min}$.

\section{Effect of surface sterilization - leaves:}

As a part of indirect organogenesis, leaves were collected, surface sterilized and inoculated in the media for the observations.

\begin{tabular}{|c|c|c|c|c|}
\hline $\begin{array}{l}\text { TREATMENT OF } \\
\text { MERCURIC } \\
\text { CHLORIDE (\%) }\end{array}$ & $\begin{array}{c}\text { NO OF } \\
\text { EXPLANTS } \\
\text { TAKEN } \\
\end{array}$ & $\begin{array}{c}\text { MORTALITY } \\
\text { RATE }(\%)\end{array}$ & $\begin{array}{c}\text { CONTAMINATION } \\
(\%)\end{array}$ & $\begin{array}{c}\text { SHOOT } \\
\text { RESPONSE } \\
(\%)\end{array}$ \\
\hline $0.1 \% \mathrm{HgCl}_{2}-3 \mathrm{~min}$ & \multirow{10}{*}{20} & $91 \pm 0.44$ & 9 & 0 \\
\hline $0.1 \% \mathrm{HgCl}_{2}-5 \mathrm{~min}$ & & $93 \pm 0.47$ & 6 & $1 \pm 0.14$ \\
\hline $0.1 \% \mathrm{HgCl}_{2}-7 \mathrm{~min}$ & & $94 \pm 0.47$ & 4.4 & $1.6 \pm 0.14$ \\
\hline $0.1 \% \mathrm{HgCl}_{2}-9 \mathrm{~min}$ & & $98 \pm 0.48$ & 2 & 0 \\
\hline $10 \% \mathrm{NaOCl}-20 \mathrm{~min}$ & & $76 \pm 0.35$ & 15 & $9 \pm 0.16$ \\
\hline $20 \% \mathrm{NaOCl}-20 \mathrm{~min}$ & & $50 \pm 0.23$ & 32 & $18 \pm 0.28$ \\
\hline $30 \% \mathrm{NaOCl}-20 \mathrm{~min}$ & & $48 \pm 0.23$ & 21 & $31 \pm 0.19$ \\
\hline $70 \%$ Ethanol $-1 \mathrm{~min}$ & & $18 \pm 0.18$ & 17 & $65 \pm 0.31$ \\
\hline $70 \%$ Ethanol -3 mins & & $11 \pm 0.16$ & 10 & $79 \pm 0.35$ \\
\hline $70 \%$ Ethanol $-5 \mathrm{mins}$ & & $6 \pm 0.16$ & 5 & $89 \pm 0.44$ \\
\hline
\end{tabular}

Table-2: Effects of surface sterilization - Leaves

Majority of the explants survived after treatment when they were exposed to Ethanol $70 \%$ for about $5 \mathrm{~min}$. Treatment with 1and 3 min were found with slight mortality of the explants whereas treatment with Mercuric chloride and Sodium hypochlorite at various concentrations and timings exposure led to the larger rate of mortality 
and some of them were non-responsive. Shoot response was observed to $89 \%$ using Ethanol $70 \%$ as the best treatment at $5 \mathrm{~min}$. Callus formation was recorded initially which was found green in color and further transferred in the fresh medium for the formation of shoots.

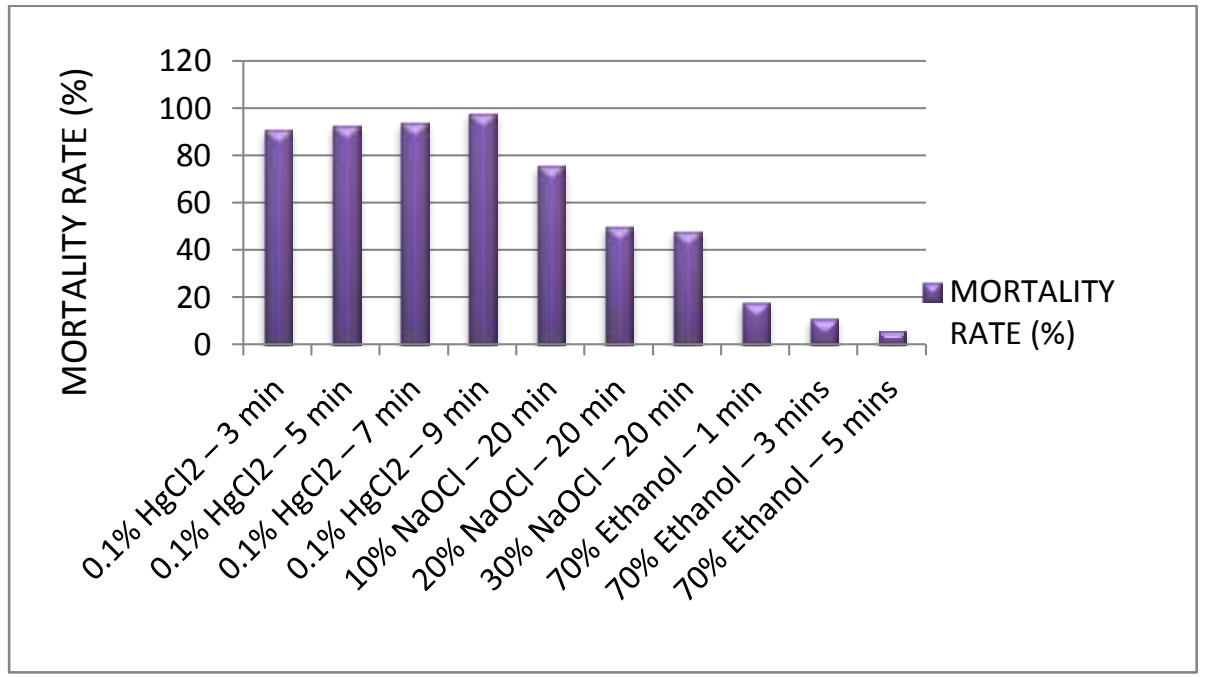

Graph 2:- Mortality rate with surface sterilants - Leaves

Initiation for shoot regeneration:

\begin{tabular}{|c|c|c|c|c|}
\hline Trial media & $\begin{array}{c}\text { No.of explants } \\
\text { taken }\end{array}$ & $\begin{array}{l}\text { No.of explants raised } \\
\text { shoots }\end{array}$ & $\begin{array}{l}\text { Mean height of } \\
\text { shoots }(\mathrm{cm})\end{array}$ & $\begin{array}{c}\text { Mean \% initiation } \\
\text { response }\end{array}$ \\
\hline \multicolumn{5}{|c|}{ Seeds } \\
\hline Im1 & \multirow{5}{*}{20} & 9.3 & 0.8 & $27 \pm 1.45$ \\
\hline $\operatorname{Im} 2$ & & 10 & 0.92 & $31 \pm 1.5$ \\
\hline $\operatorname{Im} 3$ & & 16 & 2.1 & $84 \pm 0.62$ \\
\hline $\operatorname{Im} 4$ & & 5.1 & 0.77 & $11 \pm 1.77$ \\
\hline Im5 & & 4.2 & 0.51 & $9 \pm 1.7$ \\
\hline \multicolumn{5}{|c|}{ Leaves } \\
\hline Im1 & \multirow{5}{*}{20} & 6 & 0.62 & 21 \\
\hline $\operatorname{Im} 2$ & & 9.5 & 0.87 & 29 \\
\hline Im3 & & 12.3 & 1.76 & 70 \\
\hline $\operatorname{Im} 4$ & & 15.8 & 2.05 & 79 \\
\hline $\operatorname{Im} 5$ & & 8.7 & 0.98 & 19 \\
\hline
\end{tabular}

Table 3: Initiation for shoot regeneration

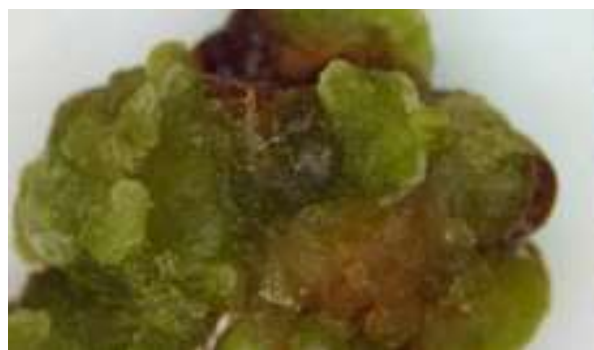

(a) Callus From Leaves

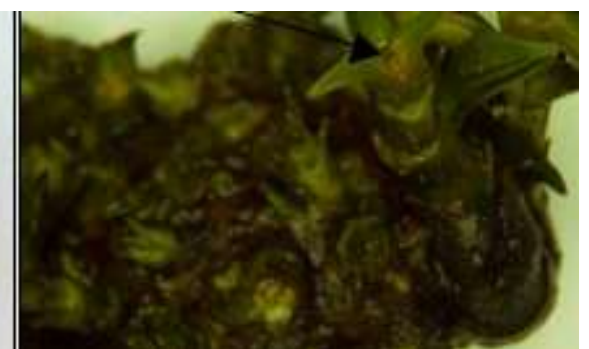

(B) Shoot From Seeds

Fig 2: Initiation Response

Initiation from seeds and leaves were observed for the response; shoot formation was noted in the seeds of about $84 \%$ with the mean height of $2.1 \mathrm{~cm}$ whereas in the leaves as explants, callus were found with lesser shoot 
regeneration; callus formation was higher of about $79 \%$ which was further transferred into other fresh media for the formation of shoots.

\section{Conclusion:-}

In this study, it was evident that the Mangosteen explants responded to Micropropagation technique because of which the cost effective large propagation can be done and the medicinal values can be utilized. This technique helps to overcome the recalcitrant difficulty faced by the mangosteen seeds. Direct organogenesis using seeds showed higher Initiation response after surface sterilization. Leaves as indirect organogenesis led to the formation of callus and transferred to next stage for the development of shoots.

\section{Acknowledgement:-}

The authors record their sincere thanks to Dr. V. Palani, Managing Director, Genewin Biotech, Hosur and Ms. S. Parvathy, R and D Manager, Genewin Biotech, Hosur for providing necessary laboratory facilities and Technical support to carry out this work in their DBT certified laboratory successfully.

\section{References:-}

1. Tran Van Minh, (2005): Application of Tissue Culture Techniques in Woody Species Conservation, Improvement and Development in Vietnam: Mangosteen (Garcinia mangostana L.) via Embryogenesis Culture. Institute of Tropical Biology, Acta Hort. 692.

2. Mohammad Hossein Torabi Sirch, M. A. Kadir, M. A. Aziz, A. A. Rashid, Arash Rafat, M.B. Javadi, (2008): Amelioration of mangosteen micro propagation through leaf and seed segments (Garcinia mangostana l.).Af. J. BiotechnoL., 7 (12): 2025-2029.

3. Ika Rostika, Novianti Sunarlim, Ika Mariska, (2008):Micropropagation of mangosteen (Garcinia mangostana).Indo. J. Agri., 1(1): 28-33

4. H. K. L. Goh, A. N. Rao, C. S. Loh, (1988):In vitro plantlet formation in Mangosteen (Garcinia mangostana 1.). Annals of Bot., 62(1): 87-93

5. Sompong Te-Chato, Mongkol Lim, (2004): Early fruit setting from tissue culture-derived Mangosteen tree. J. Sci. Technol., 26: 447-453

6. Fauziyah Harahap, Roedhypoer Wanto, Suharsono, Ciciksuriani, Sucirahayu, (2014):In vitro growth and rooting of Mangosteen (Garcinia mangostana 1.) on medium with different concentrations of plant growth regulator.Hayati J. Biosci., 21 (4): 151-158

7. Sompong Te-chato, Mongkol Lim, (1999): Plant regeneration of mangosteen via nodular callus formation. Plant Cell Tissue Organ Cult.,59 (2): 89-93. 